REVISTA DE ESTUDOS EM ARTES CÊNICAS

E-ISSN 2358.6958

\title{
Poéticas da paisagem: Experiências do ensino remoto a partir de texturas imagéticas e movimento
}

\author{
Ana Carolina da Rocha Mundim \\ Patrícia de Lima Caetano
}

\section{Para citar este artigo:}

MUNDIM, Ana Carolina da Rocha; CAETANO, Patrícia de Lima. Poéticas da paisagem: Experiências do ensino remoto a partir de texturas imagéticas e movimento. Urdimento Revista de Estudos em Artes Cênicas, Florianópolis, v. 3, n. 42, p.1-32, dez. 2021.

do DOI: http:/dx.doi.org/10.5965/1414573103422021e0109

Este artigo passou pelo Plagiarism Detection Software | iThenticate 
Poéticas da paisagem: Experiências do ensino remoto a partir de texturas imagéticas e movimento Ana Carolina da Rocha Mundim; Patrícia de Lima Caetano

Poéticas da paisagem: Experiências do ensino remoto a partir de texturas imagéticas e movimento

\author{
Ana Carolina da Rocha Mundim¹ \\ Patrícia de Lima Caetano²
}

\begin{abstract}
Resumo
O presente artigo busca compartilhar as experiências produzidas no entrelaçamento das disciplinas Laboratório de Criação: Pesquisa Corporal e Laboratório de Criação: Corpografias, assumidos respectivamente por Patrícia Caetano e Ana Mundim, nos cursos de graduação em Dança da Universidade Federal do Ceará. No contexto da crise sanitária da COVID-19, o ensino emergencial remoto das respectivas disciplinas ocorreu a partir do cruzamento da abordagem somática do Body-Mind Centering ${ }^{\text {sM }}$ e da abordagem filosófica da Antroposofia, oportunizando o desenvolvimento de trabalhos criativos pautados na relação do(a) corpo(a) com os quatro elementos da natureza em formatos visuais e/ou audiovisuais.
\end{abstract}

Palavras-chave: Dança. Improvisação. Body-Mind Centering ${ }^{\text {sM }}$. Antroposofia.

\title{
Poetics of landscape: Experiences of remote teaching from image textures and movement
}

\begin{abstract}
This article seeks to share the experiences produced in the intertwining of the disciplines Creation Laboratory: Corporal Research and Creation Laboratory: Corpographies, assumed respectively by Patrícia Caetano and Ana Mundim, in the graduation courses in Dance at the Federal University of Ceará. In the context of COVID-19's sanitary crisis, remote emergency teaching of the respective disciplines occurred from the intersection of the somatic approach of Body-Mind Centering ${ }^{\mathrm{TM}}$ and the philosophical approach of Anthroposophy, providing opportunities for the development of creative works based on the relationship of the body with the four elements of nature in visual and/or audiovisual formats.
\end{abstract}

Keywords: Dance. Improvisation. Body-Mind Centering ${ }^{\text {TM }}$. Anthroposophy.

${ }^{1}$ Pós-doutorado pela Universidade de Barcelona. Doutorado em Artes pela Universidade Estadual de Campinas (UNICAMP - 2009) e Univesitat Autónoma de Barcelona (UAB). Mestrado em Artes Unicamp (2004). Graduação em Dança Unicamp (2001). É professora adjunta da Universidade Federal do Ceará (UFC). anamundim@ufc.br

http://lattes.cnpq.br/7278100898972514

https://orcid.org/0000-0003-4257-3563

2 Doutora em Artes Cênicas pela Universidade Federal da Bahia (UFBA - 2012) e Educadora do Movimento Somático (SME) pela The School for Body Mind Centering (2015). Graduação em Psicologia pela Universidade Federal Fluminense (2002). Formação profissional em Dança Contemporânea pelo Centro de Estudos do Movimento e Artes - Escola Angel Vianna (1999). Professora adjunta dos cursos de licenciatura e bacharelado em Dança e Professora do Programa de Pós-Graduação em Artes - PPGArtes, do Instituto de Cultura e Arte/ICA, da Universidade Federal do Ceará/UFC. patriciacaetano@ufc.br

(9) http://lattes.cnpq.br/3805300292991429 (iD) https://orcid.org/0000-0003-2248-8150 
Poética del paisaje: Experiencias de enseñanza a distancia a partir de texturas de imagen y movimiento

\section{Resumen}

Este artículo busca compartir las experiencias producidas en el entrelazamiento de las disciplinas Laboratorio de Creación: Investigación Corporal y Laboratorio de Creación: Corpografías, asumidas respectivamente por Patrícia Caetano y Ana Mundim, en los cursos de graduación en Danza de la Universidad Federal de Ceará. En el contexto de la crisis sanitaria de COVID-19, la enseñanza de emergencia remota de las respectivas disciplinas se dio a partir de la intersección del enfoque somático de Body-Mind Centering ${ }^{\mathrm{TM}}$ y el enfoque filosófico de la Antroposofía, brindando oportunidades para el desarrollo de trabajos creativos basados en la relación del cuerpo con los cuatro elementos de la naturaleza en formatos visuales y / o audiovisuales.

Palabras clave: Danza. Improvisación. Body-Mind Centering ${ }^{\mathrm{TM}}$. Antroposofía. 
O ano de 2020 reservou um momento de severa alteração em nosso sistema cotidiano em função do alastramento da COVID-19, doença causada por nova espécie de coronavírus. A resposta quase imediata de todo um sistema educacional que se curvou às demandas emergenciais online criou pouco tempo para o desenvolvimento de aspectos transicionais e forçou de maneira substancialmente agressiva os(as) corpos(as) de docentes e estudantes a aceitarem esta nova conduta pedagógica. Atravessados/atravessadas por problemas de toda sorte, que inclui aspectos tácitos de acesso e acessibilidade, para além das próprias questões sanitárias, e agravamento das disparidades sócioeconômicas, não tardou muito para que o cotidiano universitário se alterasse profundamente, transformando a suposta sala de aula em um espaço que se convertia em uma espécie de confessionário das violências a que esses corpos e essas corpas eram submetidos/as diariamente. Plataformas privadas começaram a ser utilizadas para o ensino público, gravações de aulas começaram a ser solicitadas em um processo invasivo de produção de materiais, sem nenhum cuidado com direitos autorais de uso de imagem e conteúdo e/ou critérios nos modos de compartilhamento e distribuição dessas ações. A casa (agora home office) começou a receber visitas digitais sem que o morador tivesse direito de dizer não e as famílias e intimidades começaram a se tornar públicas, sem direito de questionamento. Como escapar dessa cilada construída para o ensino público? Neste contexto, nada convidativo a um processo pedagógico, nas aulas remotas emergenciais que ministrávamos no Instituto de Cultura e Arte da Universidade Federal do Ceará, gradativamente as câmeras dos/das estudantes foram se fechando, as falas foram se silenciando e docentes se viram retroagindo para um sistema bancário de ensino na qual o foco estava totalmente centrado na figura do/da docente. As poucas falas que surgiam arrastavam os corações em discursos que buscavam dividir o pesar. 
Estava claro para nós que o contexto de crise sanitária no qual nos vimos de uma hora para a outra inseridos/as diz respeito à uma crise muito maior. Uma verdadeira crise planetária que atinge os diversos planos da existência. Crise política, crise ética, crise econômica, crise educacional, crise social, crise alimentar, crise ecológica. Um vírus emerge como analisador de nosso status quo. Um vírus intervém em nossa, assim denominada, "normalidade" e nos faz questionar os modus operandis de nossa presença no mundo. Por um momento curto na história do homem sobre a Terra, um vírus enfim se impõe e dificulta a continuidade da "máquina do mundo"3. Claro estava, acionar o sensível em nossa corporalidade neste momento passaria por uma reaproximação à nossa realidade corpo-natura. Era preciso manter a chama do desejo viva em nossos(as) corpos(as) de artistasdocentes e nossos afetos alegres passavam por um experienciar a corporalidade como parte do território pulsante de Gaia4. A via da aprendizagem e experimentação de um corpo-natura dançante se apresentava como uma motivação a irrigar esse contexto educacional remoto que se evidenciava como um solo árido e ressequido para nós. Essa via se mostrava como uma bifurcação poética para corpos(as) exaustos(as) de tela e dispositivos eletrônicos, tendo em vista o fato de que vínhamos já de um semestre letivo inteiro neste sistema. No entanto, além de uma motivação poética e experiencial, esta se mostrava uma via que imprimia sentido ético-político às nossas ações artístico-docentes. Guiar corpos(as) à uma experiência de reconfiguração de seus contornos demasiadamente humanos, expandir suas fronteiras em experiências dançantes de metaformose relacional entre seres humanos e não humanos parecia fazer bastante sentido em um contexto de crise planetária em escala nunca antes vivida.

Em uma tentativa de reduzir os danos e trabalhar sobre as sensibilidades corpóreas como processo de mobilização das energias vívidas da corporalidade, decidimos experienciar a junção de dois componentes curriculares intitulados Laboratório de Criação: Pesquisa Corporal e Laboratório de Criação: Corpografias, assumidos respectivamente por Patrícia Caetano e Ana Mundim, nos cursos de

${ }^{3}$ Em referência ao poema "A Máquina do Mundo" de Carlos Drummond de Andrade, tantas vezes citado pelo pensador indígena Ailton Krenak.

${ }^{4}$ A Teoria de Gaia criada pelos biólogos John Lovelock e Lynn Margulis pensa o Planeta Terra como o maior organismo vivo existente. 
Bacharelado e Licenciatura em Dança da Universidade Federal do Ceará. A partir de referências da abordagem somática do Body-Mind Centering ${ }^{\text {SM }}$ e da abordagem filosófica da Antroposofia, acionamos os estudos dos quatro elementos da natureza: terra, água, fogo e ar. Nesse percurso algumas perguntas nos atravessavam: Como mantermos ativos os sentidos corporais, para além da visão, na prática educacional remota? Como não nos anestesiarmos em um percurso desistido de atuação sócio-educacional diante de tanto horror? Como podemos acionar o sensível em nossa corporalidade para encontrarmos lugares mais delicados e sutis de movimento?

Ao longo da trajetória destes componentes curriculares, trabalhamos cada elemento da natureza durante duas aulas seguidas, sendo a primeira orientada para conteúdos e experimentações inspirados no campo somático e a segunda para aproximações da Antroposofia na relação com a improvisação em Dança.

A Educação Somática é um campo de estudos do(da) corpo(a) vivo(a) e vívido(a) em movimento e ampliação da senso-percepção. Fazem parte desse campo diferentes práticas, abordagens e técnicas que possuem um olhar e uma compreensão do(da) corpo(a) em suas múltiplas dimensões: emocional, sensorial, cognitiva, imagética e física.

Criada pela norte-americana Bonnie Bainbridge Cohen em colaboração com uma comunidade de educadores e pesquisadores somáticos, o Body-Mind Centering $^{\text {s }}$ é uma prática somática que tem como foco central de sua proposta e estudo a consciência celular. Em sua abordagem exploramos, a partir do movimento, do toque, da sonorização e visualização, todos os sistemas corporais em sua realidade celular. Sistemas corporais, tais como, sistema esquelético, ligamentar, fascial, muscular, sistema dos fluidos, sistema dos órgãos, sistema endócrino e sistema nervoso são compreendidos e experimentados como verdadeiras comunidades celulares.

Uma célula única constitui a realidade de um organismo vivo em dimensão micro. Juntas, os conglomerados de células formam comunidades específicas como tecidos, órgãos, vísceras, glândulas, ossos, líquidos corporais que, por sua vez, formam sistemas. Cada sistema, compreendido como uma comunidade 
celular específica, carrega qualidades vibracionais e texturas diferenciadas em relação aos outros. Assim, cada sistema possui o seu próprio ritmo, sua própria pulsação e pode conferir, ao/à experimentador/a somático/a, qualidades e texturas de movimento e de presença corpórea muito diversas. Nessa abordagem, cada sistema ou tecido corpóreo pode ser experienciado como um território sensível que possibilita ao/a experimentador/a texturas de movimento variadas. No contexto desta abordagem somática, acreditamos que a corporalidade pode ser vivida como ecossistema, ou ainda, acreditamos na evidência de uma corporalidade ecossistêmica5.

No entanto, no intuito de adentrar os territórios do(da) corpo(a) por meio desta abordagem, é preciso acordar uma certa sutileza sensível própria à corporalidade. Tal sutileza sensível se faz presente na medida em que desenvolvemos uma capacidade de escuta fina aos micro-movimentos e aos fluxos vibráteis dos tecidos corpóreos, reconhecendo que a corporalidade é um espaço de atravessamentos dentro-fora. Aqui, a imagem da fita de Moebius se aproxima da realidade de nossa pele e das diversas membranas que compõem o(a) corpo(a). Ambas, pele e membranas envoltórias, constituem tecidosfronteiriços que possibilitam as trocas e as relações entre os espaços de um ambiente interno e externo. Ao relacionar e promover trocas, estes tecidos evidenciam o(a) corpo(a) como lugar de abertura e co-criação com o ambiente circundante. Portanto, nesta perspectiva, corpo(a) e ambiente seriam espaços de continuidade, atravessamentos e criação mútua. Ao entrar em contato com a realidade celular dos tecidos do(da) corpo(a), o/a experimentador/a tem a oportunidade de se reconhecer enquanto microcosmo vivo e pulsante em diálogo constante com o macrocosmo ao redor.

Nos encontros de aula, acreditávamos ser possível despertar nos/as estudantes paisagens sensíveis a partir do encontro com as texturas da própria corporeidade em diálogo com as aquelas presentes na natureza. Tais texturas eram apresentadas e vividas pelos/as estudantes por meios imagéticos e de movimento. Assim, criamos um tema geral que atravessaria e inspiraria todos os 
encontros. Nomeamos o tema Poéticas da Paisagem: Texturas Imagéticas e Movimento.

Desse modo, ancorada na prática do Body-Mind Centering ${ }^{\mathrm{sm} 6}$, a artistadocente Patricia Caetano, apresentou os quatro elementos da natureza aproximando-os de alguns sistemas e tecidos do(da) corpo(a). O elemento terra e suas qualidades de estabilidade, firmeza e nutrição, se aproximou da corporalidade por meio do sistema esquelético e do sistema dos órgãos. O sistema ósseo compõe o nosso tecido mais estável e sólido, nos proporciona o sentido de estrutura, dando-nos base de apoio, inclusive, para os pensamentos. Ao experienciar o esqueleto e seus segmentos ósseos, o/a experimentador/a vivencia a qualidade da contenção, na medida em que são as cavidades ósseas que dão abrigo e contém os órgãos. Segundo a perspectiva do BMC, os ossos seriam então o nosso continente e os órgãos o nosso conteúdo interno. Imagens de segmentos ósseos espiralados foram apresentadas em aproximação a imagens de troncos e galhos retorcidos de árvores. Já os órgãos internos foram aproximados às qualidades nutritivas e férteis da terra molhada, terra que nutre e decompõe matérias. Experimentamos por meio de diferentes qualidades de toque, a firmeza dos ossos e a maciez dos órgãos. Exploramos em movimento, acompanhados/as pelas imagens e texturas da corporalidade e da natureza. Seres-montanha e seresárvores se aproximaram de nós como parentes ancestrais, e também, como qualidades de presença, movimento e formas da corporalidade.

O elemento Ar se aproximou das dinâmicas da respiração presentes no sistema respiratório pulmonar. As qualidades da leveza, volatilidade e rarefação ligadas ao elemento Ar foram aproximadas das experiências corpóreas vividas pelas sensações aéreas de suspensão, dilatação e dispersão. Imagens dos pulmões e do diafragma respiratório, seus movimentos, ritmos e dinâmicas foram visualizadas para em seguida serem experimentados nos/as corpos(as). Ao entrar em contato com o movimento de entrada e saída do ar no(na) corpo(a) fomos remetidos às experiências aéreas do voo das asas de uma borboleta, à dispersão dos pólens das plantas e seus cheiros pela atmosfera, aos vapores que sobem na

\footnotetext{
${ }^{6}$ A partir daqui o Body-Mind Centering vai aparecer ao longo do texto através da sigla BMC.
} 
direção do céu, às diversas qualidades do vento. As ações de Voar, Plainar, Vaporizar ou Evaporar, Respirar foram vividas em imagens, texturas e movimentos dançantes.

O elemento Fogo foi apresentado em aproximação ao sistema circulatório, o sangue e o coração. Este elemento foi trazido pela discente do Programa de PósGraduação em Artes - PPGArtes, Germana Brito, que fez seu tirocínio docente nesta disciplina sob a supervisão da profa. orientadora Patricia Caetano. Germana aproximou as qualidades quentes do sangue pulsante à esse elemento, evidenciando também a dimensão política revolucionária do fogo transformador e sua presença em diferentes danças étnicas, como por exemplo, a dança da pombagira presente na umbanda e a dança de Xangô presente no candomblé.

O elemento Água foi vivenciado por meio dos fluidos de base propostos pelo BMC, são eles: fluido celular, fluido intersticial e fluido transicional. Aqui a realidade celular, suas dinâmicas e seus ambientes fluidos interno e externo foram aproximados das qualidades de fluidez, transporte, diluição ou solubilidade e estado de liquefação presentes no elemento Água. Cada um dos três fluidos de base foi apresentado a partir de sua qualidade específica e estado de presença que evocam nos(as) corpos(as). Pequenos vídeos de águas calmas de lagoa, águas pulsantes de mar e água corrente de rio foram associadas aos três fluidos de base. Assim, as imagens e texturas da corporalidade e da natureza se relacionaram. As sensações de umidade, imersão líquida e dissolução foram estimuladas na corporeidade através de um objeto relacional ${ }^{7}$ chamado saco d'água. Cada estudante foi orientado a criar o seu próprio saco d'água a partir de um saco plástico de supermercado preenchido com água, fechando a abertura do saco com um nó. Este saco d'água foi utilizado para estimular a pele do(da) corpo(a) e ativar a presença dos fluidos corporais, como também, as memórias e sensações fluidas nos(as) corpos(as). Ações de Fluir, Boiar, Mergulhar, Diluir ou Dissolver, Escorrer, Gotejar, Lubrificar foram vividas por meio de texturas moventes e mobilidades imagéticas da corporalidade dançante. 
As experiências somáticas eram propostas sempre nos primeiros encontros de cada elemento. Já nos segundos encontros, os/as estudantes puderam pesquisar e criar movimentos a partir da abordagem da Antroposofia em conjunção com a prática da improvisação em dança. A Antroposofia (sabedoria do homem), na abordagem de Rudolf Steiner, pressupõe que o ser humano aglutina quatro estruturas: o corpo físico (de estrutura material - ligado ao elemento terra), o corpo etérico (força responsável pelo princípio da vida - ligado ao elemento água), corpo astral (forças da consciência, veículo de sensações e sentimentos ligado ao elemento ar) e a organização do - ego (que distingue o homem de outros seres da natureza, entidade espiritual - ligado ao elemento fogo).

O modo de interação desses(dessas) corpos(as) definem quatro tipos de temperamento: melancólico, fleumático, sanguíneo e colérico. Cada temperamento possui características distintas, tendo algumas tendências. O melancólico (corpo físico/terra) é alguém que costuma a sentir prazer na dor, frequentemente desconfiado/a, introvertido/a, egoísta, pessimista, inflexível, mas são pessoas dedicadas, leais e de muita sensibilidade. O fleumático (corpo etérico/ água) é uma pessoa pouco disposta a abrir-se ao mundo exterior, procrastinadora, egoísta, indecisa, desmotivada, por outro lado é tranquila, sua presença sugere aconchego, é diplomata e inspira confiança. O sanguíneo (corpo astral /ar) se perde em sensações intensas e passageiras, não retém interesse em somente um objeto, é instável emocionalmente, indisciplinado, exagerado, mas em contraponto é cordial, amigável, entusiasta e compreensível; o colérico (ego/fogo) impõe seu eu, é irado, sarcástico, dominador, insensível e tem como pontos fortes ser visionário, prático, decidido e líder.

Quando uma pessoa identifica a dominância de algum desses temperamentos, isso facilita com que ela se perceba de modo mais evidente e possa refletir sobre as potencialidades que ela pode explorar de forma mais intensa e as fragilidades que ela precisa desenvolver, muitas vezes, inclusive, na aprendizagem coletiva com alguém de temperamento distinto. A principal proposta é que se busque um equilíbrio. Experimentar a busca por esse equilíbrio em movimento torna as investigações corpóreas mais evidentes, contribuindo para a auto-percepção e a sensibilização da corporeidade e da auto-crítica. 
das áreas de conhecimento, sugestões de vídeos e conversas com os/as estudantes. E na segunda parte da aula provocávamos espaços de criação por meio da improvisação. A partir da inspiração da Vivência Prática do Sensível, produzida durante a pandemia pela artista Dudude, Ana Mundim articulou saídas para espaços isolados da natureza, visando a gravação de aulas a serem compartilhadas com os/as alunos/as. Os vídeos e descrição das propostas eram disponibilizados aos/as estudantes via sistema (SIGAA UFC) e youtube, para que eles pudessem desenvolver suas vivências sensíveis. A partir desses estudos, eles/elas poderiam desdobrar, como produção criativa, diários de bordo e materiais audiovisuais (vídeos ou fotografias, preferencialmente em grupos).

Os materiais produzidos pelos/as estudantes tinham uma relação íntima com a maneira como suas corporalidades se despertavam nas nuances da cotidianidade pandêmica. Suas angústias, seus sabores, seus questionamentos, suas expectativas, seus desejos emergiam das palavras e criações artísticas.

Uma dupla de estudantes cedeu suas imagens para compartilharmos. O resultado do trabalho por eles produzido, denominado ANSIAr, reflete seus atravessamentos ao longo do isolamento social e como os elementos da natureza se conectaram com suas sensações. Para o aluno Matheus Costa:

Resumindo a experiência da disciplina em uma palavra, gosto de pensar em "sensação". Desde o início, as professoras Ana Mundim e Patricia Caetano, que ministravam as aulas para Laboratório de Criação: Pesquisa Corporal e Laboratório de Criação: Corpografias, optaram por trazer aos alunos possibilidades de experimentações através da nossa relação com os elementos da natureza: terra, água, fogo e ar.

É estranho pensar que estávamos experimentando com os elementos sozinhos e ao mesmo tempo em conjunto com o resto da turma devido ao modo de aula remota, mas isso só foi possível graças à possibilidade de usar objetos e "imagens sonoras" em nossas práticas.

No elemento Água, foi possível sentir que a água é, de fato, parte majoritária do corpo humano. Quando nos foi proposto examiná-la com o intuito de perceber suas propriedades físicas e sensíveis através do toque, foi bom "conhecê-la" de uma forma não automática, já que é um elemento que não está muito em relação com as minhas vivências.

No elemento Terra, do qual menos experimentei por questões outras, foi perceptível a presença dos corpos físicos e do meu próprio corpo (ou eu 
próprio corpo, se pensarmos que um corpo não se limita apenas em físico, mas também no psíquico) ao meu redor. Sentir o que pisa no mesmo chão e que ocupa um espaço próximo ao meu foi e é importante não só pra mim, mas para qualquer corpo dançante.

No elemento Ar, a experiência pesada e fixa da Terra foi substituída por algo leve, delicado, mas presente. Digo substituída porque o modo de experimentação foi alterado mas acredito que as sensações vivenciadas anteriormente ficam em você e nas coisas ao seu redor para sempre. Importante afirmar que não significa que foi uma experiência confortável, na verdade foi a experiência mais considerável na minha passagem pela disciplina. Aqui segue uma imagem retirada de meu diário de bordo:

"Uma janela grande no segundo andar de uma casa em um espaço de tamanho médio, muito ar vindo do azul claro do céu aberto e das árvores no quintal da vizinha. Um corpo que dança leve, rápido, constante e expandido. O corpo cansa e de repente o ar que o toca naquela sala não é o mesmo ar que entra em seus pulmões. Lembranças de um tempo confinado, acordado em plena madrugada, tentando respirar o ar que agora vem do céu azul escuro. Não há ar algum. Ansiedade."

No elemento Fogo, um misto de atravessamentos: o calor da proposta experimentada por mim me faz querer viver. A libido sobe ao máximo, o sangue corre rápido, minha mente vira uma festa com muita dança, corpos em contato, álcool nas veias, desejo e prazer em níveis altos. Tudo é (era) bom.

Como resultado final, decidi, ao lado da minha colega de classe, Isabella Nantua, transformar as sensações em fotos, fotos dançadas, projeto que chamamos de "ANSlar". Um trabalho feito com cuidado, com (re)vivências boas e ruins. Foi delicado. Foi nossa arte.

Já, a estudante Isabela Nantua pontua sobre o trabalho:

Escolhi dois elementos, ar e fogo, por me lembrarem das sensações tão presentes no isolamento pandêmico. Um sufocamento me é presente até hoje e a falta de ar me inunda em momentos de crise. Com ela vem a raiva, o afogueamento. O calor dentro do peito e o rosto vermelho é como meu corpo reage à cólera de estar presa dentro de mim. Durante a produção das fotos, respirar dentro da sacola me deu desespero, agonia e tontura, exatamente como me sinto nesse momento atípico. E o cinto me trouxe o sangue para a cabeça.

As imagens que seguem foram resultantes desse processo. Ambos produziram autorretratos. 
Poéticas da paisagem: Experiências do ensino remoto a partir de texturas imagéticas e movimento

Figura 1 - Projeto ANSlar - Autorretrato Matheus Costa

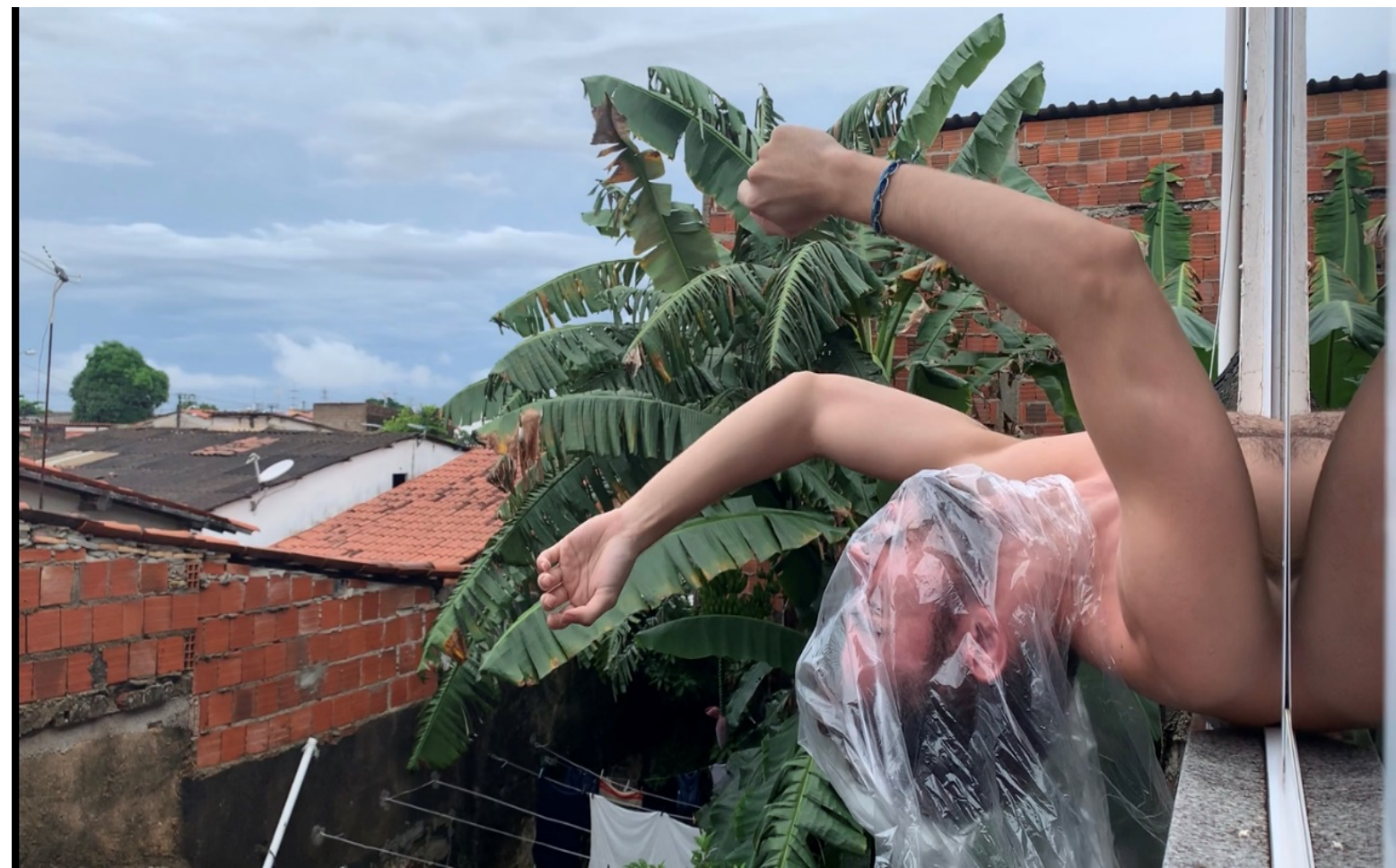

Figura 2 - Projeto ANSlar - Autorretrato Matheus Costa

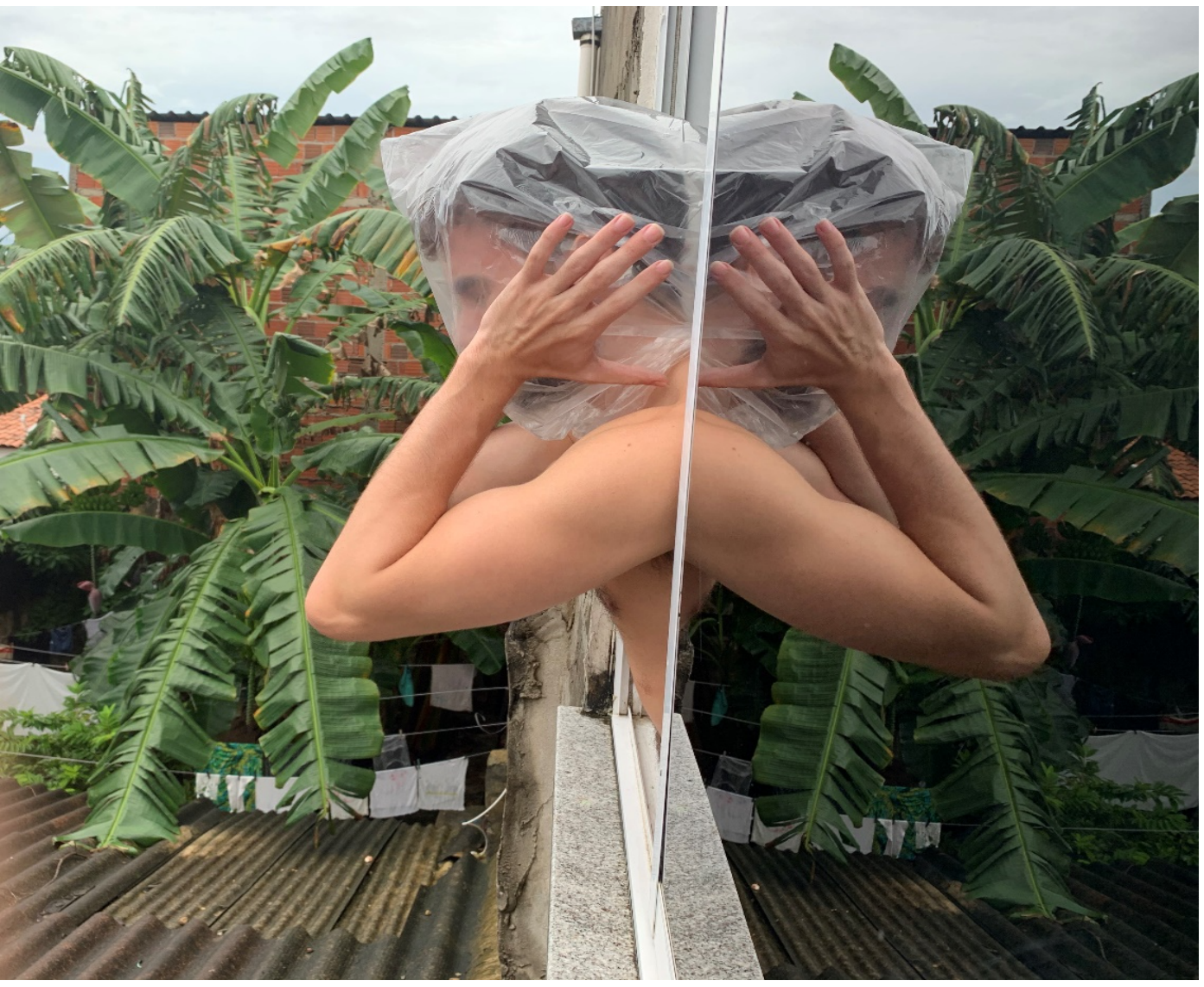


Poéticas da paisagem: Experiências do ensino remoto a partir de texturas imagéticas e movimento Ana Carolina da Rocha Mundim; Patrícia de Lima Caetano

Figura 3 - Projeto ANSlar - Autorretrato Matheus Costa

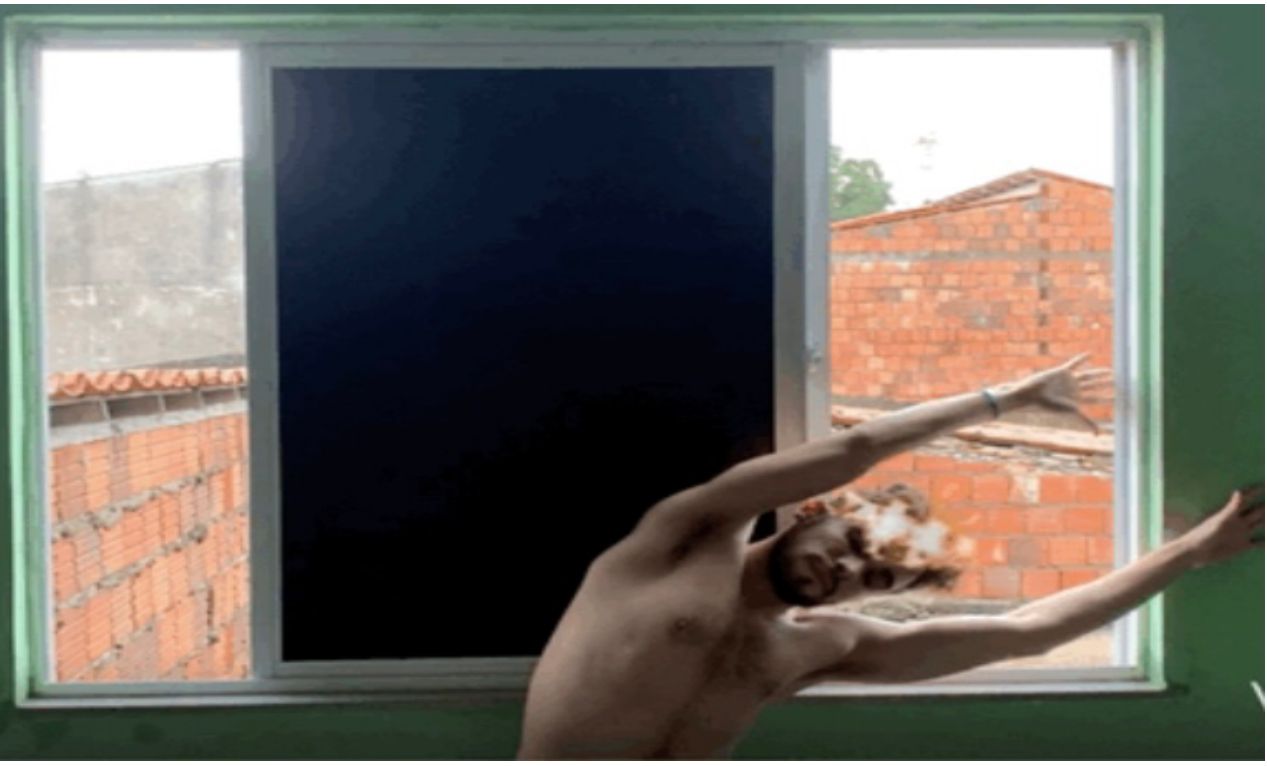

Figura 4 - Projeto ANSlar - Autorretrato Isabela Nantua

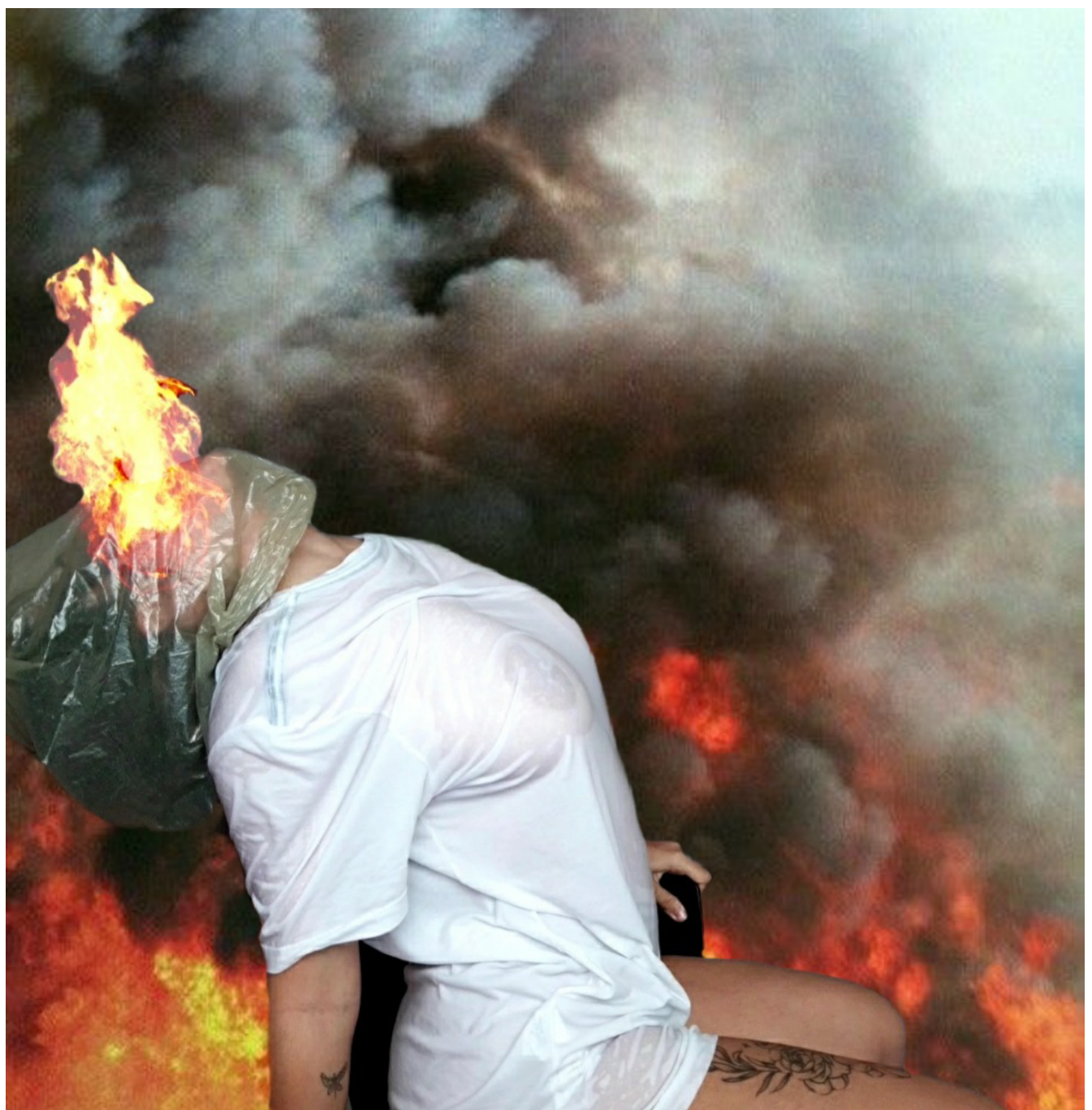


Poéticas da paisagem: Experiências do ensino remoto a partir de texturas imagéticas e movimento Ana Carolina da Rocha Mundim; Patrícia de Lima Caetano

Figura 5 - Projeto ANSlar - Autorretrato Isabela Nantua

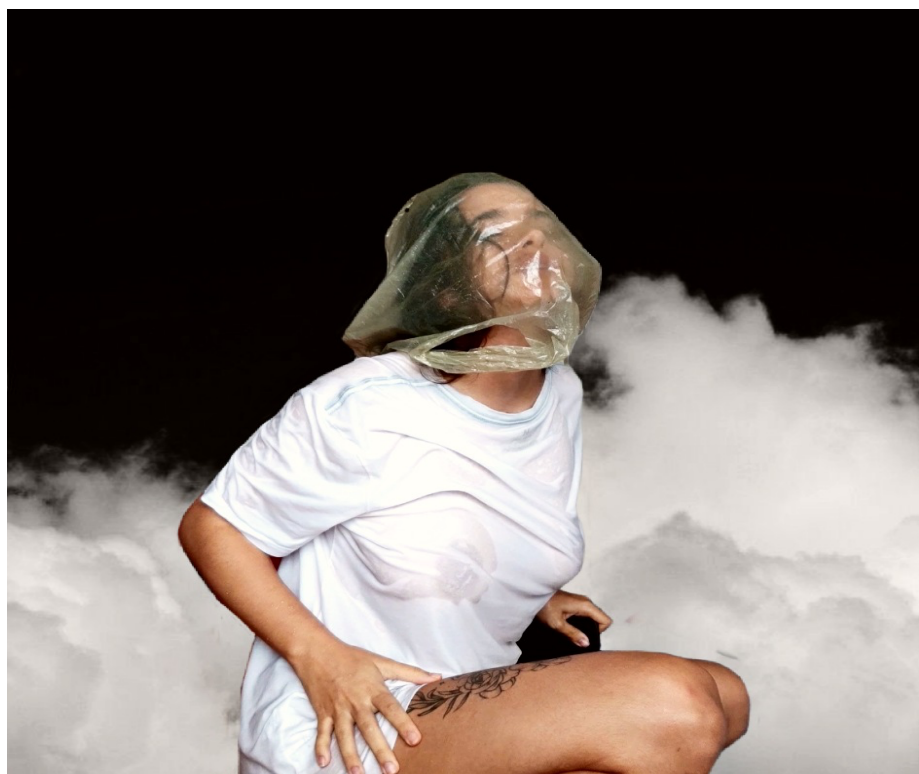

Figura 6 - Projeto ANSlar - Autorretrato Isabela Nantua

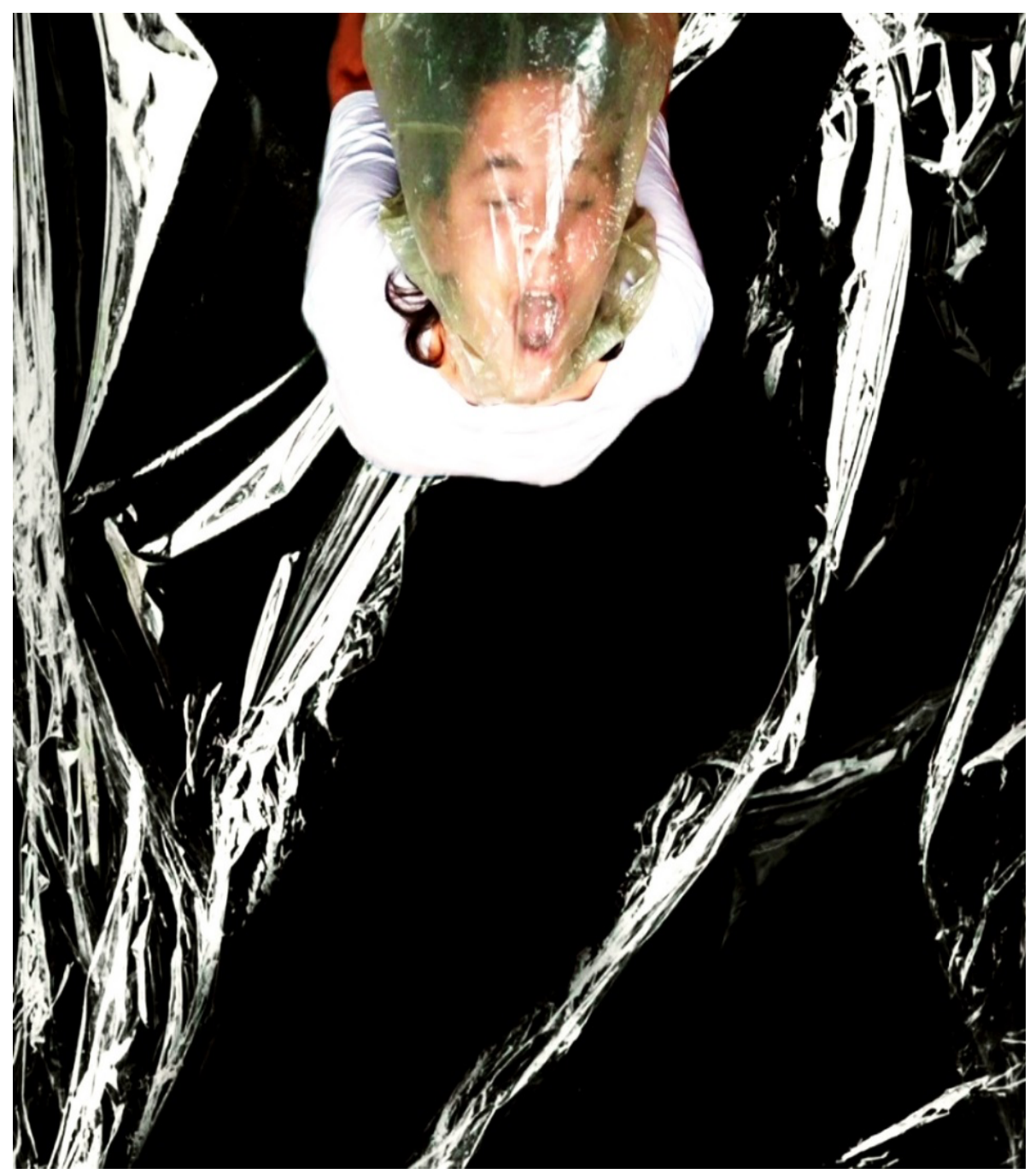


Poéticas da paisagem: Experiências do ensino remoto a partir de texturas imagéticas e movimento Ana Carolina da Rocha Mundim; Patrícia de Lima Caetano

Figura 7 - Projeto ANSlar - Autorretrato Isabela Nantua

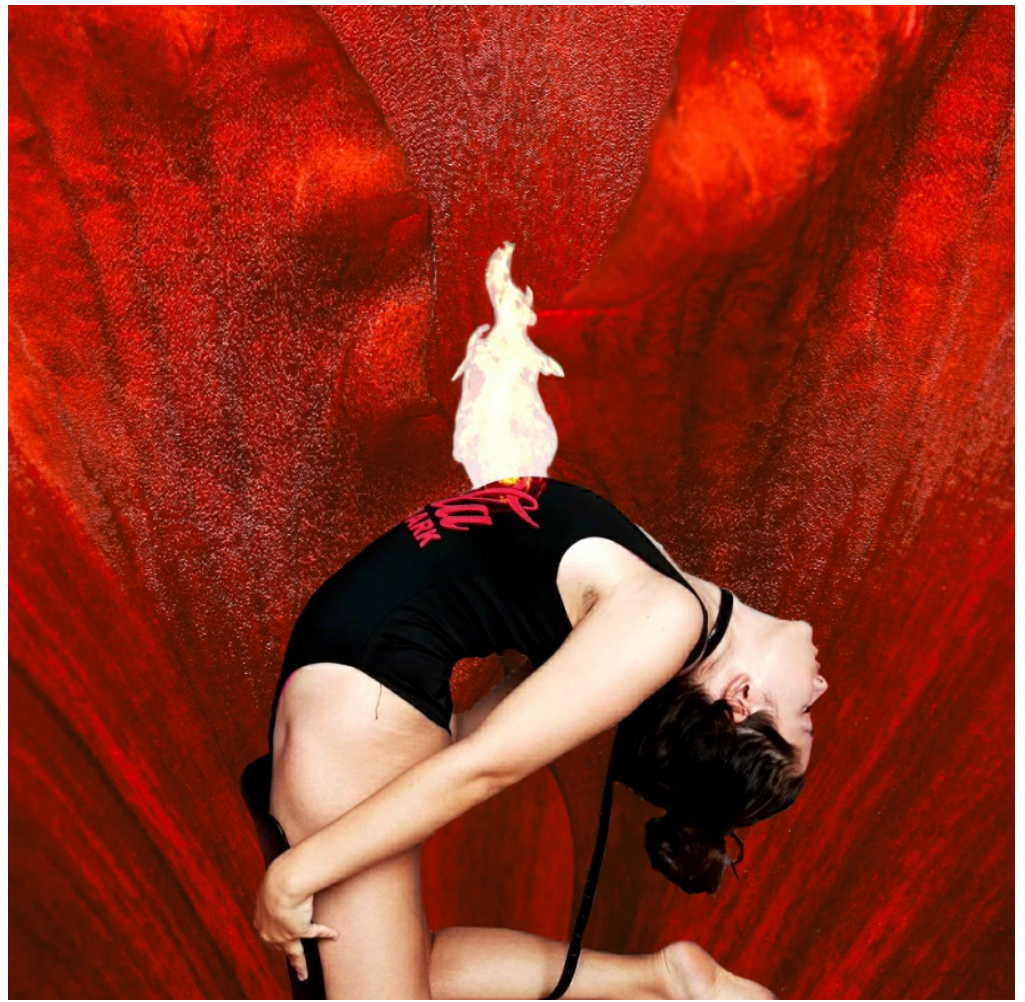

Figura 8 - Projeto ANSlar - Autorretrato Isabela Nantua

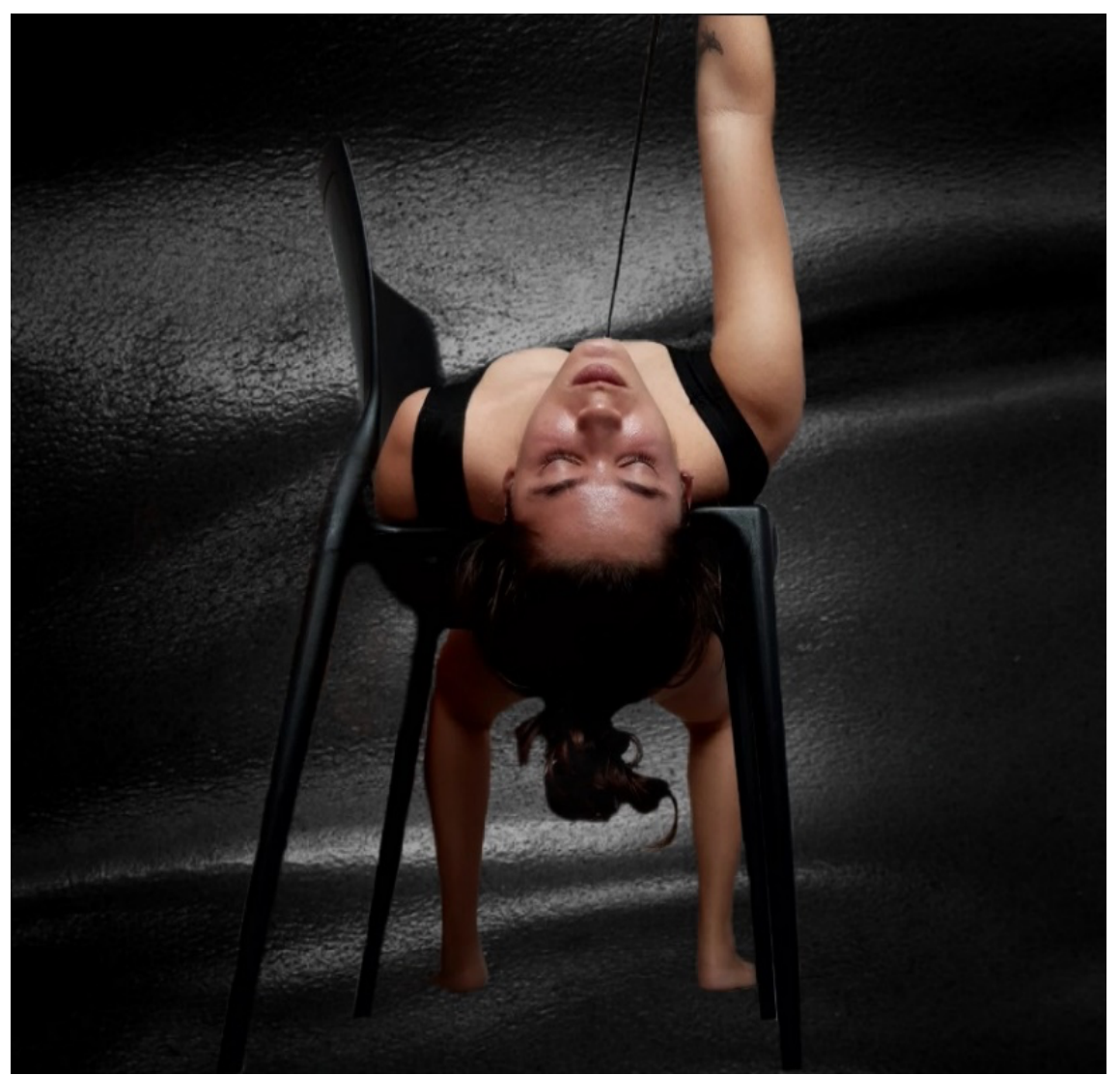




\section{Experimente você também}

A partir dessa experiência, fazemos o convite para que você, leitor/a, acompanhe corporalmente as guianças que compartilhamos a seguir e saboreie sua corporeidade sensível.

Aula na relação com o elemento Terra - Guiança Ana Mundim

Este é o link referente à experiência sensória: https://youtu.be/n5X56QPhYXc, cuja descrição está abaixo.

Hoje vamos trabalhar sobre o elemento Terra. Vamos começar tentando nos conectarmos com o solo que nos acolhe, que nos impulsiona, que nos traz força e resistência. Com os pés bem apoiados no chão, tentamos abrir a musculatura, sentir a textura do piso onde estamos, a temperatura, mapeando, desenhando o solo, com a sua pisada. Perceba o modo como você apoia os pés no chão, como você distribui seu peso, como essa terra amortece seu peso, te empurra, como você cede seu peso para a terra e como a terra se relaciona com esse peso que você entrega para ela.

Aos poucos perceba a negociação da sua musculatura pra te manter de pé, o que você cede, o que você resiste. Sinta essas possibilidades de alargamento dos pés no solo, como esse pé vai ganhando espaço e se espalhando e como isso reverbera no resto do(de) seu(sua) corpo(a). Enquanto mapeamos o solo com os pés, o(a) nosso(a) corpo(a) também é mapeado(a), o(a) nosso(a) corpo(a) é mapeado(a) como espaço e esse espaço é mapeado como corpo(a). E onde quer que vocês estejam nesse momento, tentem perceber aonde vocês pisam, qual a textura de onde vocês pisam, como é a pisada de vocês.

Começamos lentamente a mover os dedos dos pés como no miudinho do samba tentando mastigar a terra com os pés e percebendo, na medida que realiza esse movimento, como o resto do(da) corpo(a) responde ao contato com a terra. Quais desenhos você constrói e o que leva junto com você? Por outro lado, o que é deixado nessa terra onde o(a) corpo(a) se move? 
Apoiamos novamente os pés por inteiro no chão, a partir dos calcanhares e começamos a pensar nesses pés como raízes de árvores, como se debaixo das solas dos pés fôssemos plantando raízes que ficam imersas no solo e que vão constituindo um(a)corpo(a)-árvore. Como é o desenho desse(dessa) corpo(a)árvore? Plantados, como podemos começar por essas raízes, que se comunicam debaixo do solo, a criar espaços de movência para os joelhos, para o quadril, para a coluna, para a cabeça, para os ombros, para as mãos? Como você permite esse(essa) corpo(a) criar caule que vai se espreguiçando pro céu, formando os galhos, as folhas, as copas das árvores? Aos poucos fazemos o caminho de volta percebendo como retornar do alto das copas para o chão, para o solo. Como você começa aos poucos a deslizar esses pés, deixa a terra começar a se mover, delineando trajetórias no solo, demarcando possibilidades de movência? Quais são os sons desse solo onde você está nesse momento, quais as texturas, os cheiros, o que esse solo provoca no(na) seu(sua) corpo(a)? Quais são os desenhos construídos nesse lugar onde você está? Se são desenhos visíveis é possível olhar, tomar contato com a visibilidade dessas trajetórias que se produziu com o movimento? Se não são visíveis há essa percepção interna dos desenhos criados? Quais caminhos o(a) corpo(a) percorre a partir desse mergulho dos pés no solo?

Após deslizar esses pés pela terra, depois de perceber quais são os movimentos, qual a poeira que sobe desse deslizamento, iniciam-se as possibilidades de pulso. Quais são os pulsos desses pés no solo? Lembrando dos pulsos da nossa ancestralidade, das nossas culturas negras, indígenas, quais os pulsos dos nossos ancestrais nos (nas) nossos (nossas) corpos (corpas)? O que fica, quais os vestígios, quais as novas construções, quais as desconstruções? Cada um(a) vai criando seu pulso, seu pulso, seu pulso. Terra, com a terra, para a terra, da terra. Como esse pulso dança em mim? Como esse pulso dança em você? Vai construindo, reconstruindo, identificando, encontrando, desencontrando, mas principalmente aterrando, aterrando, aterrando, aterrando. Cada um(a) seguindo no seu pulso, deixando o pulso dos pés que sentem a movência da terra entrar por todo(toda) corpo(a) e reverberar. Quais os pequenos movimentos que a gente encontra na terra? Como esses movimentos vão criando latências no(na) nosso(nossa) corpo(a), criando maior volume, uma tridimensionalidade? Os 
próprios pulsos e impulsos que nascem da terra, jorram sementes e fazem brotar. O que desejamos para esse solo? O que desejamos plantar nesse solo? O que desejamos desse(dessa) corpo(a)-terra? O que encontramos nesse(nessa) corpo(a)-terra? Quais os frutos queremos plantar? E aos poucos esse pulso é encontrado: o ritmo desse pulso, a musicalidade desse pulso, a dança desse pulso. Tente encontrar qual a sua dança-terra. Como a firmeza da terra vai trazendo chão pro(pra) nosso(nossa) corpo(corpa) e vai reverberando para além da materialidade visível dele.

Quem quiser reduzir esse pulso, aumentá-lo, criar pequenas pausas a partir dele, vai encontrando essas possibilidades, mas sem deixar de perceber o que encontra no solo. O que sente do solo? O que brota do solo? Comecem a construir pequenas passagens entre a verticalidade e o nível baixo, tentando cada vez mais se aproximar do solo, revolvê-lo, encontrar outras possibilidades de contato de todo(toda) corpo(a), de uma parte do(da) corpo(a). Como se empurra esse solo, se descola dele, retorna-se para o nível alto? Se perceba como árvore, permita que a árvore cresça, se expanda, crie os galhos. De lá de cima, retorne, construindo esse espaço que volta pra terra, pra debaixo da terra, para além. Daqui de onde brota se constroem novos caminhos do caule, dos galhos, das folhas, das copas, para desse movimento ser reconstruído o retorno para o solo, voltando, escorrendo, deslizando, mergulhando, cavando, encontrando espaços no chão.

Cada um(a) experiencia essa possibilidade de aproximação e afastamento do solo sem perder a conexão com a terra, sem perder a conexão consigo e com as possibilidades ancestrais que se apresentam no(na) corpo(a) de vocês. Enquanto se movem na aproximação e no afastamento encontrando o que há debaixo do solo, costurando caminhos para além do solo, entendam como isso se delineia no(na) corpo(a). Qual a densidade, qual a respiração, qual a cor, qual o cheiro, qual o tom? Qual o som? Qual a escrita, qual a memória, qual a imagem, qual o desenho, qual a mancha, qual alegria, qual a dor? Qual o peso, qual a leveza? Qual a estrutura, qual a desestrutura? Qual a altura, qual a proximidade, qual o afastamento, quais os movimentos? Quais as nervuras? 
Aos poucos vamos percebendo como o solo compõe os movimentos e como os nossos movimentos recompõem o solo. Como nos nutrimos desse solo para dançar, para reverberar no espaço e como espaço, como geramos nutrição para o solo? Como o(a) corpo(a)-terra se firma nas suas necessidades, nos seus desejos? Como esse(essa) corpo(a)-terra dança a vida e as questões que habitam os seus cheiros, os seus toques, as suas dúvidas, as suas possibilidades?

Como esse solo resiste e produz resistência e a como a dança que brota dele também o faz? Quais os sonhos brotam desse solo dançado? Quais as forças habitam nesse solo dançado? Quais as histórias habitam esse solo dançado? Quais as memórias desse solo dançado? Quais ainda estão por serem construídas e sendo construídas aqui e agora? Qual a luz desse solo, qual a sombra desse solo? Como o descanso reside nesse solo? Qual a respiração desse solo que dança? Esse solo-corpo-que-dança, esse solo-corpa-que-dança. E, aos poucos, vai construindo a sua própria musicalidade, pulsação dança-terra, e deixando a terra criar sua própria musicalidade. Como se dança a terra, como você se dança terra, como a terra the dança? Permitam-se agora experimentar o que brota disso. Cada um tem um tempo de 10 minutos para permitir-se dançar a terra que habita em si, para depois, em uma roda de partilha, contarmos que dança é essa. Reverência à nossa mãe terra.

Aula Ar - Guiança Ana Mundim

Este é o link referente à experiência sensória: https://youtu.be/naloQF4geyY, cuja descrição está abaixo.

Hoje vamos trabalhar a partir do elemento ar. Proponho que vocês comecem percebendo o(a) corpo(a) de vocês, o ar que o(a) percorre. Qual o caminho que ele organiza no(na) corpo(a)? Esse ar que entra e sai do(da) corpo(a). Como vocês mapeiam esse percurso? Nesse momento em que falta oxigênio para o(a) corpo(a) humano no nosso País, Brasil, nesse momento que tem faltado oxigênio para a natureza em função de uma intervenção humana agressiva, dessa perspectiva do Antropoceno, vamos perceber o ar em nós, em um momento em que a gente volta se entender como natureza. Permitam-se, aos poucos, a ouvir o som do ar, cada um de seu próprio espaço, percebendo-o dentro de si e no seu entorno, deixando- começar a mobilizar a sua coluna e percebendo a integração que a sua coluna 
promove com o restante do(da) corpo(a). Como esse ar se transformar em movimento, como esse ar se transforma em palavra, como esse ar se transforma em som no(na) seu(sua) próprio(a) corpo(a)? Como a mobilidade que esse ar provoca na coluna, ao preencher sua caixa torácica e depois esvaziá-la, reverbera no restante do(da) teu(tua) corpo(a), provocando movimento, provocando gesto, provocando palavra, provocando canção? Permita-se mergulhar nesse ar que é você.

Percebam as mobilizações que se dão em cada mínima parte do(de) seu(sua) corpo(a). Comecem a se aprofundar no imaginário dos grãos de areia que se movem com o ar das dunas móveis do nosso Ceará. Qual a topografia que esse(essa) corpo(a)-duna, que nos compõe desenha no espaço onde nos encontramos agora? Como esse(essa) corpo(a)-duna chega na casa de cada um(a)? Como esse ar permite que as topografias do ambiente que somos se modifique em alguns momentos lentamente e em outros momentos rapidamente, na gestualidade, no movimento, na nossa corporalidade? Comecem a perceber com que velocidade esse ar entra e sai do(da) corpo(a) de vocês. Como isso se dá organicamente? Como se pode alterar essa velocidade também, tornar a respiração mais lenta, mais rápida? Como a gestualidade e a movimentação respondem a isso? O que acontece se você deixa de respirar por alguns segundos? Quando você permite que o ar saia do(a) corpo(a), que tipo de gesto, de movimento, de topografia, se cria e se desenha a partir dessa ação?

Comecem a explorar um pouco as maneiras como se pode experimentar a entrada e a saída de ar. Brinquem com possibilidades: reter o ar por alguns segundos, soltar o ar lentamente, rapidamente reter o ar, rapidamente soltar o ar, inspirar e soltar o ar rapidamente, inspirar len-ta-men-te, soltar o ar... lentamente... vão percebendo nessas experiências quando o ar se faz brisa? Quando o movimento se faz brisa? Quais são as micro possibilidades de movimento do(da) corpo(a)? Percebam as micro possibilidades de alteração da topografia que esses micro movimentos podem trazer a partir do ar que se desloca, que desloca seu(sua) corpo(a), que se desloca como espaço. Permitam-se ouvir o som do ar, que habita seu(sua) corpo(a), que é seu(sua) corpo(a). Quais os novos desenhos se configuram como espaço a cada movência do(de) seu(sua) corpo(a)-ar? Até onde 
esse ar se faz brisa? Em que momento esse ar começa a se desenhar como vendaval?

Esse ar como vendaval, de que forma corta o espaço, cruza o espaço, avança como espaço? Como esse ar se dispersa? Como esse vendaval dança? Que vendaval há dentro de você e como esse vendaval que há dentro de você ocupa o mundo, ocupa a sua arte, a sua dança, o seu modo de mover?

Crie sua própria musicalidade, deixando, inclusive a voz tomar lugar na sua movimentação, deixando esse ar também poder se transformar em música, em canção, em sussurro, em palavra. Percebam as ondulações desse(dessa) corpo(a)ar e as possibilidades de intencionalidade do gesto e do movimento que também vão se descobrindo, redescobrindo, modificando, trazendo novas topografias e brincando com as intensidades. O que há entre seu(sua) corpo(a)-brisa e seu(sua) corpo(a)-vendaval? Quais são as nuances que se estabelecem entre esse(essa) corpo(a)-brisa e esse(a) corpo(a)-vendaval?

Quais são as danças que se organizam com o vento? Quais são as danças que se constroem, que se reconstroem, que se fazem, se desfazem, se descobrem, se escondem, se revelam, se organizam, reorganizam e desorganizam? Quais os tempos dessas danças, dessas danças que dançam com o vento, que são o vento? Como a gente percebe o privilégio diário de respirar? Como a gente percebe e agradece o privilégio diário de estar vivo? Como a gente percebe o modo como esse(a) corpo(a) que é natureza cria topografias de movimento, danças, arte?

Como esse(a) corpo(a), que é duna móvel, se recompõe, se refaz, renasce, a cada instante? Quais as possibilidades de criação poética e sensível se estabelecem na nossa corporalidade, olhando esse ar que afeta os grãos de areia.... grãos de areia que podem ser tão bonitos e tão suaves, mas que também podem entrar pelos poros, pelos olhos e incomodar, gerar fricção? O que a gente constrói com o ar que a gente respira? Que tipo de humanidade a gente constrói, que tipo de arte a gente constrói, que tipo de dança a gente constrói? Com quem a gente dança? Quais as sua danças e como elas se conectam com o mundo? Como se devolve para o mundo, generosamente, o movimento do(de) seu(sua) corpo(a), da sua dança, da sua arte, em retribuição a esse ar que se respira todos os dias, que 
se recebe todos os dias? E como cada vez mais se pode entender o(a) corpo(a) como natureza? Entender o(a) corpo(a) como mais um elemento da natureza, entender que o mundo não é sobre você, é sobre nós. É sobre essa coresponsabilidade com o ar que a gente respira, com o que a gente produz a partir desse ar.

Como finalmente a gente volta a perceber que o humano não é algo apartado da natureza? Talvez sejamos apenas mais um grão de areia compondo esse grande universo e se encontrando nessa dança do vento. Permitam-se nos próximos 10, 15 minutos, a identificarem qual a paisagem ou quais as paisagens estão no(na) corpo(a) de vocês a partir do ar que vocês estão movimentando nesse momento aonde vocês estão, nas condições que cada um(a) está. Quais as danças você cria a partir disso? Quando teu ar é brisa, quando teu ar é vendaval? Quais as nuances teu(tua) corpo(a) percorre nesse entremeio?

Vou me despedindo por aqui. Fiquem livres agora pra experimentar essa dança-vento, essa dança-ar, em silêncio, com alguma música, ou fazendo com que sua própria voz gere musicalidade por meio de palavras, sons, murmúrios, sussurros, canções. Até mais.

Nesse dia assistimos alguns vídeos que nos inspiraram poeticamente. São eles:

Voice, dos Ebinum Brothers -

https://www.youtube.com/watch?v=S73ncwiw4PM

F Makor, Hania Rani - https://www.youtube.com/watch?v=bB34 eLCLKo

Também foi construída uma playlist colaborativa para o componente: https://open.spotify.com/playlist/OoERAqH1YQHfqMyYbnV2wc?si=aFZszFcrR byLl4l6-whsYQ

Guiança da aula sobre Fogo - Ana Mundim

Este é o link referente à experiência sensória: https://youtu.be/IKhdivrsX04, cuja descrição está abaixo. 
Hoje nós vamos começar sentados(as), de olhos fechados. Antes de começarmos a nos mover quero convidar vocês a embarcarem em um exercício imaginativo. Vamos imaginar que estamos todos(as) sentados(as) em volta de uma linda fogueira. Lentamente vamos friccionando as mãos para produzir calor e quando as mãos estiverem bem quentes vamos deixar que elas toquem nosso rosto, permitindo a transmissão desse calor. Nesse lugar vamos pensar em quais memórias aparecem em nosso(a) corpo(a) quando pensamos na palavra fogo. Deixem essas memórias percorrerem a coluna de vocês, como uma pequena chama que vai acendendo aos poucos e preenchendo os espaços vazios. Permitam que essas memórias dancem fisicamente em vocês e enquanto a coluna as mobiliza vocês deixam que as mãos continuem produzindo calor na pele a partir da friç̧ão no restante do(da) corpo(a). Deixem as mãos deslizarem, friccionando o(a) corpo(a) de vocês. E na medida em que mobilizamos essas chamas de memória na coluna e que friccionamos as mãos no(na) corpo(a), provocando calor, vamos nos permitindo sair do chão e encontrarmos novas mobilidades para nosso(nossa) corpo(a), aquecendo-o cada vez mais, transferindo as mãos para outras partes do espaço, que não só o(a) corpo(a), e deixando que as chamas das memórias percorram a coluna, cada vez mais se mobilizando e crescendo. Comecem a permitir que essas chamas se dissipem em fumaça. Tentem imaginar como se a produção desse calor pelo toque das mãos no(na) corpo(a) fosse provocando o surgimento de fogo nos ossos, como se os ossos fossem gravetos de madeira que vão produzindo esse fogo. E quanto mais friccionamos, mais o calor aumenta, mais chamas produzimos, mais brasa. E a partir de agora não paramos mais de nos movimentarmos e daqui em diante vamos deixando esse fogo iluminar o espaço de forma crescente. Até que momento esse fogo acolhe nosso(a) corpo(a), o(a) aquece deixando-o(a) confortável? E em que momento começamos a transitar para sair desse lugar de conforto e deixamos a coluna aumentar o fogo produzido, fazendo a brasa saltar desse(dessa) corpo(a)-fogueira? Como, aos poucos, lançamos chamas pelo espaço, compartilhando essas memórias-fogo, lançando essas memórias através da coluna? O fogo simboliza a vida, conhecimento intuitivo, paixão. É um símbolo regenerador. Como renovamos o(a) corpo(a) nessa dança? Como pensamos em sua propriedade de transmutação? O que lançamos para o fogo queimar e 
transformar? Como fazemos crescer a labareda? Como iluminamos o espaço? Como lidamos com essa energia crescente? E como intensificamos ainda mais a movimentação e a transmutação de energias? Como cuidamos para identificar em que momento esse fogo ainda nos acolhe e acolhe ao(à) outro(a) e em que momento esse fogo começa a nos queimar ou queimar o(à) outro(a)? Como mobilizamos essa coluna labareda dançante fazendo as chamas atravessarem o alto da cabeça, o sexo, as pontas dos dedos dos pés e das mãos? Como nesse processo de transmutação a gente desloca de um lugar a outro, muda de uma circunstância para outra, transforma esse(essa) corpo(a)espaço? Como transformamos esse ambiente-casa? Como deixamos a movimentação cada vez mais intensa e crescente, percebendo novas memórias que chegam ao(à) corpo(a) ou que brotam dele? Como produzimos mais energia por meio dessa colunalabareda de fogo? Como vamos expandindo esse fogo, deixando-o crescer cada vez mais, e mais, e mais, e mais, e mais, e mais, e mais, e mais, e mais, e mais, e mais, e mais... permitam seus (suas) corpos(corpas) transcenderem para outros lugares imaginativos, de pensamento, liberem a intuição e as possibilidades de movência sem se preocupar com formas. Lancem as faíscas no espaço, aproveitem a oportunidade de transformar questões ruins ou desagradáveis que estão habitando o(a) corpo(a) em energias positivas, transformem em algo que alimente seu entorno e a vocês mesmos ou vocês mesmas. Deixem as chamas fluírem em saltos, em giros, em espirais, em diferentes níveis, em fluxo e refluxo. Permitam-se com a música deixar esse (essa) corpo (corpa) em chamas dançar. Se enebriem com essa dança! Iluminem o espaço, esse dia, a semana. Iluminemse! Permitam o(a) corpo(a) ser condutor(a) dessa luz pela dança, buscando o prazer de dançar, de aquecer o mundo, de transmutar as energias! Quando acabar a música fiquem um tempo com vocês mesmos, vocês mesmas, até a chama reduzir e aos poucos nos reconectarmos ao grupo. Dancem, dancem, dancem em torno da fogueira, com a fogueira, sendo a fogueira!

Nesse dia assistimos novamente alguns vídeos como referências. São eles:

Performance Cassils: $\quad$ https://www.cassils.net/cassils-artworkinextinguishable-fire\#performance 
Poéticas da paisagem: Experiências do ensino remoto a partir de texturas imagéticas e movimento

Correfoc (Barcelona/ Espanha) https://youtu.be/EbvlEm IKwE

Dança do fogo (Polinésia Francesa) https://youtu.be/YzVdlEXUr34 (o próprio youtube faz a tradução automática do texto se vocês configurarem)

Fireknife dance battle - old school/ new school (Polinésia Francesa): https://youtu.be/esDzXOkuX4k old school/ new school

Trechos do documentário Fogo Sagrado: https://youtu.be/GhQDMUSoCyQ

Ritual do Fogo Sagrado na abertura dos jogos olímpicos indígenas em Paragominas, no estado do Pará: https://youtu.be/Tu8v OkNnEk

Guiança Aula Água - Ana Mundim

Este é o link referente à experiência sensória: https://youtu.be/oynfzStkxDQ, cuja descrição está abaixo:

Hoje nós vamos para nossa aula na água, com a água e como água. Vamos começar sentindo os fluidos que percorrem o (a) nosso (a) corpo (a), tentando lembrar do (a) nosso (a) corpo (a) em contato aquele saquinho cheio de água dentro, que vai se mobilizando, se readequando enquanto espaço quando se move. Percebam a fluidez, a delicadeza, a suavidade dos movimentos. Percebam o fluxo que é forma e que também disforma, encontrando a transparência, o lugar translúcido do (da) corpo (a) e do movimento. Observem como o líquido se acomoda, se reacomoda e como o (a) corpo (a) aos poucos vai começando a entender esse novo volume, o balanço da água, as reverberações que a água gera enquanto espaço quando é movida e quando se move. A água nos compõe internamente, balança dentro de nós, gera ondas dentro de nós. Qual a força da suavidade? Como essa água habita a pele, as entranhas, os órgãos? Quais os desenhos, os rascunhos, as escritas que essa água vai criando enquanto dança? Como essa água amacia o (a) corpo (a)? Como esse (a) corpo (a) começa a se perceber enquanto água, ultrapassando a percepção apenas do que é visível da nossa matéria corpo (a) e começando a compreender as invisibilidades e as imaterialidades que nos habitam? Como essa água desliza nessa dança? Como essa água que me preenche enquanto corpo(a) vai criando espaços de movência em um ir e vir macio? Qual a temperatura desse(a) corpo(a)-água? Como 
começamos a trazer uma leveza, como se essa água nos fizesse boiar, como se esse(a) corpo(a) fosse carregado por essa água, sustentado, suspenso por ela? Como esse(a) corpo(a) suspenso dança, se move, gira, sobe, afunda, boia, flutua e volta a afundar? Aos poucos pensamos no(na) corpo(a) que afunda como um navio embaixo do mar, naufragado. Como ele (ela) convive com os (as) outros (as) corpos (as) que ali habitam? Como ele (a) deixa esse corpo(a) pesar no fundo da água? E a partir da ideia de flutuar, de boiar, a gente vai soltando o peso e buscando a imagem de afundar o(a) corpo(a). E no fundo, como se percebe que esse(a) corpo(a) que pesa de água se desloca? Qual o som do silêncio do fundo da água? Esse(a) corpo(a) submerso(a) vai aos poucos começando a encontrar suas possibilidades de espiralar como as ondas, como as reverberações da água. E vamos começando a buscar outro estado da água que revolve o espaço. Como torço o(a) corpo(a) água como as ondas, gerando bolhas, pequenas reverberações, encontrando outra intensidade da água? Como saímos das águas mais tranquilas e buscamos a água que corta, fura o espaço? Uma água que se revolta, que vem e vai, que se retorce, que resiste, que empurra, que rebenta? Como mexer as águas internas e o que modifica no(na) corpo(a) quando essas águas tranquilas começam a encontrar o movimento de ir e vir, criando ondas e se movendo por elas? Tentem perceber esse(a) corpo(a) que se mareia e que pode até tontear. Um(a) corpo(a) que perde a referência exata de tempo e espaço. Um(a) corpo(a) que se desorienta na sua aquosidade, ampliando suas percepções, suas sensações, suas emoções e se permite perder o controle, deixando a água que compõe a corporalidade levarse pela dança como água. Permitam-se navegar, ser onda, gerar onda, mobilizar o espaço, deixando essa água extrapolar os limites que tentam restringi-la, permitam que o horizonte comece a surgir. Uma água que se expande no horizonte se apresenta. Sintam-se corpo(a)-água diluindo as fronteiras que criamos para nosso(a) corpo(a). Produzam um momento para dançarem a água que vocês são, deixando o horizonte invadir o(a) seu corpo(a), deixando-se atravessar várias intensidades da água, tendo prazer e sabor em ser água. Fiquem livres para dançar, movendo as águas até nos reencontrarmos. 
Poéticas da paisagem: Experiências do ensino remoto a partir de texturas imagéticas e movimento Ana Carolina da Rocha Mundim; Patrícia de Lima Caetano

Seguem alguns links de vídeos que foram referências nesse encontro.

Vídeo compartilhado pelo estudante Raffael Tomaz após a prática: https://www.instagram.com/p/CLXJQIXn-fV/?utm source=ig web copy link

Vadim Slovyov - https://www.instagram.com/p/B5He7AQliEM/

Fotografias de Christy Lee Rogers - http://www.christyleerogers.com/

Between Music's AquaSonic: Breaking the surface https://www.youtube.com/watch?v=EKLBSwdSMH4

Making off do video acima: https://youtu.be/Fdf3r1nUEdw

Sob o céu do silêncio - Ana Mundim - https://youtu.be/WSh5g7bXuOY

Ama - vídeo: https://www.youtube.com/watch?v=bdBuDg7mrT8

Making off: https://www.youtube.com/watch?v=Cl85pzpki1M

Esculturas do fotógrafo, escultor Jason Taylor https://www.greenmebrasil.com/viver/arte-e-cultura/1002-jason-taylor-esuas-esculturas-submarinas/

Another place - Antony Gormley: https://youtu.be/Qw W08Y5a8s

Antony Gormley - TED: https://youtu.be/vJ66jv8ICjc

Ascenção de Tristão: Bill Viola: https://youtu.be/Gqf cuDf9ql

O Segundo sopro: Rosely Rodrigues: https://youtu.be/7uvKYoUP1ks

1999 - Balé do Teatro Guaíra - cena água a partir do minuto 48:40

8 artistas e a água - https://www.youtube.com/watch?v=j-Gih7feKul

Ysani Kalapalo - Relação indígena com a água: https://youtu.be/fQe0o2cfJQA $0: 33$

Vídeo 4 elementos da natureza - Bill Viola - Martyrs https://www.youtube.com/watch?v=1_ZcloGeRIQ 


\section{Conclusões}

Como apresentamos no início desta escrita, partimos de perguntas iniciais que nos impulsionaram/estimularam à criação de um modo outro pedagógico durante o momento desafiador do isolamento social imposto pela pandemia. Relembramos aqui as perguntas disparadoras: Como mantermos ativos os sentidos corporais, para além da visão, na prática educacional remota? Como não nos anestesiarmos em um percurso desistido de atuação sócio-educacional diante de tanto horror? Como podemos acionar o sensível em nossa corporeidade para encontrarmos lugares mais delicados e sutis de movimento?

Ao escrever esse texto, olhamos em retrospectiva para um percurso motivado pelo território pulsante de Gaia que agonizava (e ainda agoniza) em nossas próprias corporeidades. Sufocamento, falta de ar, ansiedade, depressão, crises de enxaqueca, síndrome do pânico, síndrome de burnout são apenas alguns dos nomes que imprimimos à essa experiência agonizante provocada pela desconexão de nossos(nossas) corpos(as)-natura. Como organismos vivos que somos, organismos contíguos ao organismo vivo Gaia, apuramos nossa escuta, ressonamos e padecemos junto à ela. No entanto, o veneno se faz também antídoto. Apurar a escuta da corporeidade sensível, nesta via de aprendizagem, dizia respeito também à uma busca pela nossa sanidade mental, emocional, física e energética. Uma sanidade somático-antroposófico-dançante.

Como nos relatou o estudante Matheus Costa, a via da aprendizagem e experimentação de um(a) corpo(a)-natura dançante através da prática somática, da Antroposofia e da improvisação em dança se apresentou como uma via de aprendizagem através das sensações. Sentir o(a) corpo(a)-natura ao despertar dos sentidos e do movimento, procurando dissolver a primazia do sentido da visão constituiu um dos nossos dispositivos pedagógicos. Era preciso des-hierarquizar o sentido da visão, demasiadamente sobrecarregado pelas telas e dispositivos eletrônicos em aulas remotas e atividades nas redes sociais. Em nossa proposta de aprendizagem, as imagens apresentadas consistiam em paisagens repletas de 
texturas: paisagens táteis, sonoras e moventes. Trazer para a experiência remota a possibilidade de contato com uma abordagem que partia da observação dos sentidos da natureza, traduzidos em vídeos especialmente gravados para cada aula, ativava outros espaços de percepção nos(nas) participantes e os(as) reconectava com as sensações de estar se movendo ao ar livre. O estímulo ao imaginário e às zonas poéticas cognitivas também reconfiguravam a maneira dos(das) estudantes se aproximarem dos conteúdos com maior suavidade e leveza.

O resultado dos trabalhos finais que acompanharam a proposta destes componentes curriculares, aqui representados pelo trabalho final des estudantes Matheus Costa e Isabela Nantua, nos dão um retorno importante deste processo vivido. As paisagens moventes em diálogo com as materialidades de nossos/as corpos/as nos aproximaram de nossa realidade corpo(a)-natura e nos auxiliaram em um processo de reconfiguração e ressignificação da agonia pandêmica. Reconhecemos que o tema geral - Poéticas da Paisagem: Texturas Imagéticas e Movimento - que atravessou e inspirou as docentes e suas proposições a cada encontro, também se desdobrou em diversas práticas criadas pelos/as estudantes.

Assim, os resultados nos demonstram que cada trabalho apresentado elaborou uma poética da paisagem onde as texturas imagéticas e o movimento dos(das) corpos(as)-natura materializaram uma reconfiguração singular de cada grupo de estudantes. No caso de Matheus e Isabela, reconhecemos em ANSIAr uma poética da paisagem embalada pelos elementos fogo e ar, por meio da qual a subjetividade e a corporeidade encontraram uma oportunidade de reconfiguração ético-estético-política.

Avaliamos, portanto, que a metodologia construída para esse percurso despertou novos ânimos aos(às) estudantes participantes, para reativarem suas sensibilidades adormecidas, anestesiadas. Também provocou o interesse na escrita por meio dos diários de bordo, muitos deles tendo expandido as anotações para outras vivências fora do espaço do componente curricular, entrelaçando percursos, inclusive de ordem cotidiana, com os conteúdos das aulas. Percebemos, ainda, que a produção criativa em pequenos grupos, apesar da 
condição remota, fez com que fosse retomado certo desejo e algum espírito de coletividade que estava se dissipando nas práticas pedagógicas desse período de pandemia.

Não apenas os videodanças e os ensaios fotográficos apresentados, como as leituras públicas de seus diários e os feedbacks a respeito das aulas, nos trouxeram a certeza de que encontramos um caminho profícuo de sensibilização a partir de materialidades e imaterialidades corpóreas, apesar da distância. Desse modo, concluímos que, sim, esta proposta de uma experiência educacional remota ancorada pela via das sensações, aqui apresentada, nos dá sinais de que conseguimos irrigar o solo árido e ressequido de nosso contexto educacional em tempos de pandemia. Esperamos poder continuar semeando novos solos em continuidade.

\section{Referências}

ANDRADE, Carlos Drummond. A Máquina do Mundo. Disponível em:https://www.letras.com.br/carlos-drummond-de-andrade/a-maquina-domundo Acesso em: 15 jun. 2021

CAETANO, Patricia de Lima. Por uma Estética das Sensações: o corpo intenso dos Bartenieff Fundamentals e do Body-Mind Centering. Revista Brasileira de Estudos da Presença, Porto Alegre, v.5 n.1, jan./abr. 2015.

CLAVEL, Joanne; GINOT, Isabelle. Por uma Ecologia da Somática? Revista Brasileira de Estudos da Presença. Porto Alegre, l 5, n.1, jan./abr., 2015.

COHEN, Bonnie Bainbridge. Introdução ao Body-Mind Centering. In: Sentir, Perceber e Agir. São Paulo: Edições Sesc, 2015.

KRENAK, Ailton. Ideias para adiar o fim do mundo. São Paulo: Cia. Das Letras, 2019.

KÖNIG, Karl. Os quatro temperamentos. Arte Médica Ampliada. V. 33 | N. 1 | Janeiro/Fevereiro/Março de $2013 . \quad$ Disponível em: http://abmanacional.com.br/arquivo/61a408f632ba631567aef84d60a1b9142d0f864 d-33-1-temperamentos.pdf. Acesso em: 21 jan. 2020.

LOVELOCK, James. Gaia: Um Novo Olhar Sobre a Vida na Terra. Edições 70, 2020.

MUNDIM. Ana Carolina (org.). Abordagens sobre improvisação em dança contemporânea. Uberlândia: Composer, 2017. 
OSTROWER, Fayga. Criatividade e Processo de Criação. Petrópolis: Vozes, 2008.

PENEDO, Ana Letícia Penedo. Os quatro elementos da natureza e a educação do sensivel. 70 congresso pesquisa do ensino. Disponível em: http://www1.sinprosp.org.br/conpe7/revendo/assets/trabalho_conpe2.pdf. Acesso em: 21 jan. 2020.

Recebido em: 16/06/2021

Aprovado em: 30/09/2021 